International Journal of Geography and Geology

2022 Vol. 11, No. 1, pp. 1-12.

$\operatorname{ISSN}(e):$ 2305-7041

$\operatorname{ISSN}(p): 2306-9872$

DOI: $10.18488 / 10 . v 11 i 1.2899$

(C) 2022 Conscientia Beam. All Rights Reserved.

check for
updates

\title{
THE REGION OF METLAOUI FACING SEISMIC HAZARDS: STUDY AND CARTOGRAPHIC APPROACH (South Atlas of Tunisia)
}

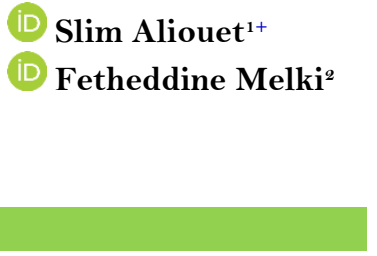

Article History

Received: 28 October 2021

Revised: 2 December 2021

Accepted: 20 December 2021

Published: 14 January 2022

\section{Keywords}

Metlaoui region

Seismotectonic

magnitude

Mapping

Hazards

Vulnerability

Active fault.
'CGMED Laboratory, Faculty of Arts and Humanities of Sousse, Tunisia.

Email:aliouetsalim@gmail.com

${ }^{\circ}$ Laboratory of Geodynamics, Geonumeric and Geomaterials (LR18ES37), Faculty of Sciences of Tunis, Tunis El Manar University, Tunisia.

Email:fetheddine.melki@fst.utm.tn

\section{ABSTRACT}

Contribution/Originality: This study contributes to define the zones of strong seismicity, and to show that the faults of Gafsa-Séhib, Metlaoui-Mtalga and Metlaoui-Thèlja constitute an irrefutable argument for the neotectonic activity in southwestern Tunisia, as well as the existence of a link between these faults and the seismic activity recorded at Metlaoui.

\section{INTRODUCTION}

On November 7, 1989 at 5:48 p.m., the city of Metlaoui (South Atlas of Tunisia) Figure 1 experienced a relatively intense seismic activity (Aliouet, 2017; Dlala, 1992; Dlala \& Hfaidh, 1993). The epicenter of this tremor was located a few kilometers south of the Metlaoui city. This earthquake, of magnitude 4.4, caused panic among the local population; it was arguably the most important in the region of Metlaoui since the last event of 22 May 1972 with Ms 4.2 (Aliouet, 2017; Dlala \& Hfaidh, 1993; Said, 2011).

Current ongoing research on the assessment and understanding of seismic hazard has been discussed by several authors. Allen, Griffin, Leonard, Clark, and Ghasemi (2020); Allen, Griffin, and Clark (2018a) summarizes the evolution and the development of the seismic risk understanding in Australia 2018 (NSHA18), study the depth treatment of the epistemic uncertainties associated with the risk model improved in the catalog of earthquakes and identify the dominant factors causing the changes resulted from the hazard. The work of Rashad, José, and Peláez (2020) in United Arab Emirates, Qatar and Bahrain, shows a probabilistic assessment of the seismic hazard in terms of maximum ground acceleration (PGA) and spectral acceleration values (SA ), for a probability of exceeding 10\% and $5 \%$ in 50 years. Three alternative ground motion attenuation models for crustal earthquakes and one for those of intermediate depth were selected and an applied catalog of Poisson earthquakes was prepared for this work. 
Ghasemi et al. (2020) study the region of Papua New Guinea (PNG) where the level of seismicity poses significant risks. The results of the updated seismic zoning map suggest a new probabilistic assessment and better understand the spatial distribution of seismic risk.

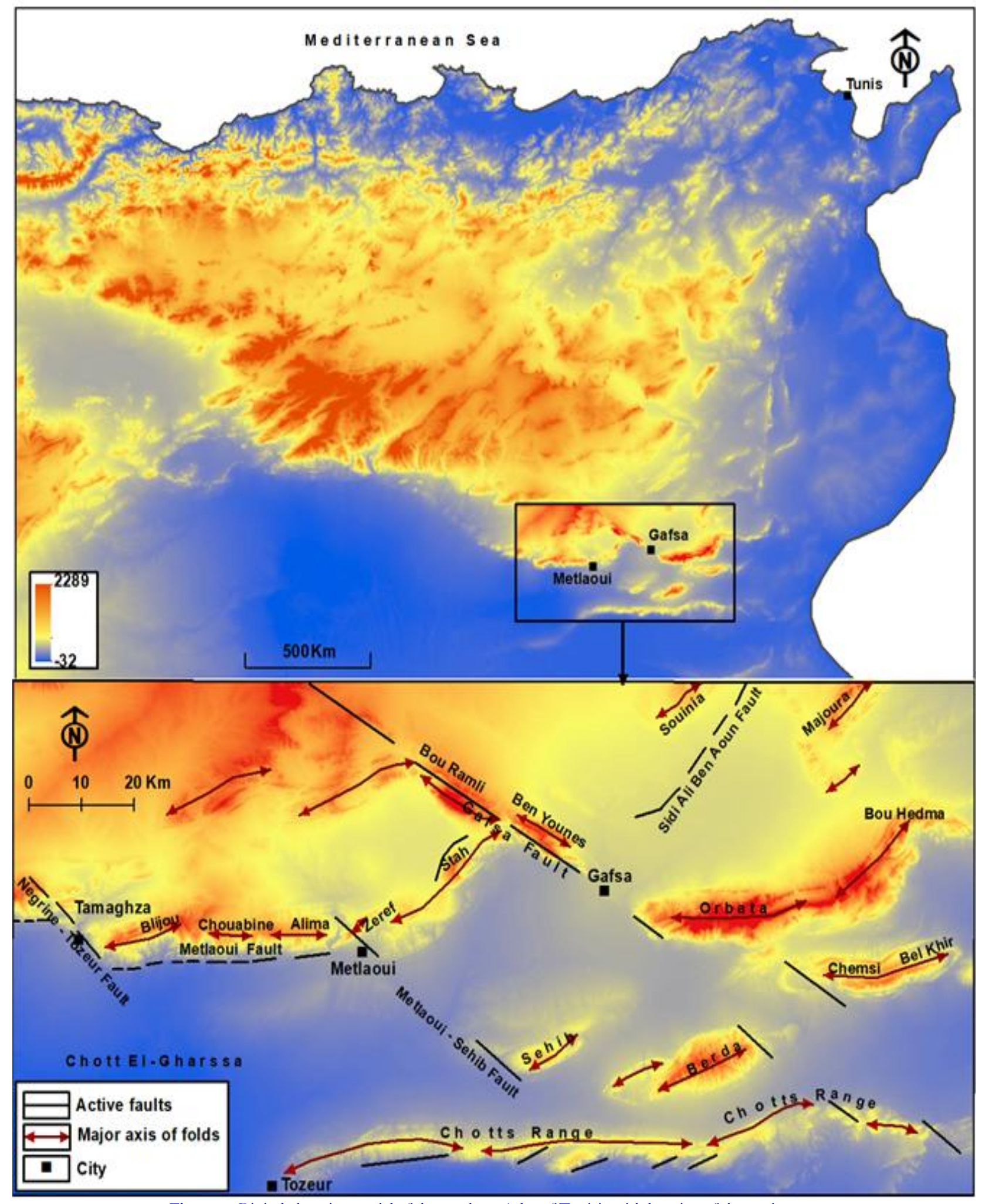

Figure 1. Digital elevation model of the southern Atlas of Tunisia with location of the study area.

Understanding seismic hazard is one of the fundamental objectives in earthquake monitoring. Seismic hazard is commonly evaluated as a measure of the largest event that may occur. This is important as it dictates the level of 
strong ground motion that may be induced by a seismic event, which is closely related to the potential for damage. A commonly referenced definition of seismic hazard is: "An estimation of the mean probability (over space and time) of the occurrence of a seismic event with a certain magnitude within a given time interval." The challenges in estimating seismic hazard are clearly highlighted in this definition with regard to the uncertainty involved in "mean probability", "certain magnitude" and "within a given time interval". Therefore, it is necessary to quantitatively analyze and discuss these three areas when predicting earthquake risk.

The seismic events that occurred in the city of Metlaoui caused enormous damage to property. This work is based on a macroseismic investigation initiated on the major event that affected the city of Metlaoui (Southern Tunisia) through a cartographic approach; it consists:

- To examine the influence of neotectonics in the arrangement of geomorphological landscapes;

- Identify the role played by active faults in the appearance of the seismic hazard;

- To understand the seismogenic source of the seismic events recorded in this;

- To study the manifestations of the seismic hazard in the Metlaoui region;

- To determine the damage caused by the event of November 7, 1989;

- To highlight the links between the evolution of the urban space and that of the exposure to seismic hazards.

\section{MATERIALS AND METHODS}

The various cartographic, photographic and satellite data and the very high resolution images used for the study and mapping of the seismotectonic, the morpho-tectonic framework and the seismic hazard are presented in Table 1.

Table 1. Data used

\begin{tabular}{l|c|c|c}
\hline Database & Date & Scale & Title \\
\hline Topographic maps & 1957 and 1993 & $1 / 100000$ and 1/50000 & Metlaoui and Gafsa \\
\hline Geological map & 1985 & $1 / 100000$ & Metlaoui \\
\hline \multirow{2}{*}{ Aerial photographs } & 1952 & $1 / 25000$ & Chain of Metlaoui \\
\hline \multirow{2}{*}{ ASTER satellite image } & 1963 & $1 / 25000$ & $1 / 60000$ \\
\hline Landsat ETM+ image 2001 & 1990 & $15 \mathrm{~m}$ & Chain of Metlaoui \\
\hline Very high resolution Google image & 2000 & $30 \mathrm{~m}$ & Chain of Metlaoui \\
\cline { 2 - 4 } & 2001 & $15 \mathrm{~m}$ & $10 \mathrm{~m}$ \\
\cline { 2 - 4 } & 2012 & $5 \mathrm{~m}$ & Chain of Metlaoui \\
\hline
\end{tabular}

The data used were geo-referenced in the same coordinate system: UTM projection-Zone 32 - and WGS 84 ellipsoid reference under ENVI software (Exelis-Visual Information Solutions, USA). All these layers were held within a Geographical Information System (ArcGIS, ESRI, USA).

The contribution of cartography to the approach of the seismic hazard required the collection of bibliographic information related to this topic, the collection of possible information on topography, geology, morphology and its links with neotectonic activity, seismology (historical and instrumental seismicity) and field research to control and update the information collected.

The general methodology for the representation of the sisimic hazard is illustrated in Figure 2. Data processing methods, data sources and fieldwork and surveys are reported.

Quaternary tectonics and geology in the southwest of Tunisia were studied by several authors (Aliouet, 2017; Aliouet, Soudani, Melki, \& Ahmed, 2020; Ben-Ouezdou, 1994; Castany, 1953; Castany \& EG., 1954; Coque \& Jauzein, 1965; Gasmi, 2012; Roux, 1911; Said, 2011; Vaufrey, 1932; Zargouni, 1984; Zargouni, 1986). 


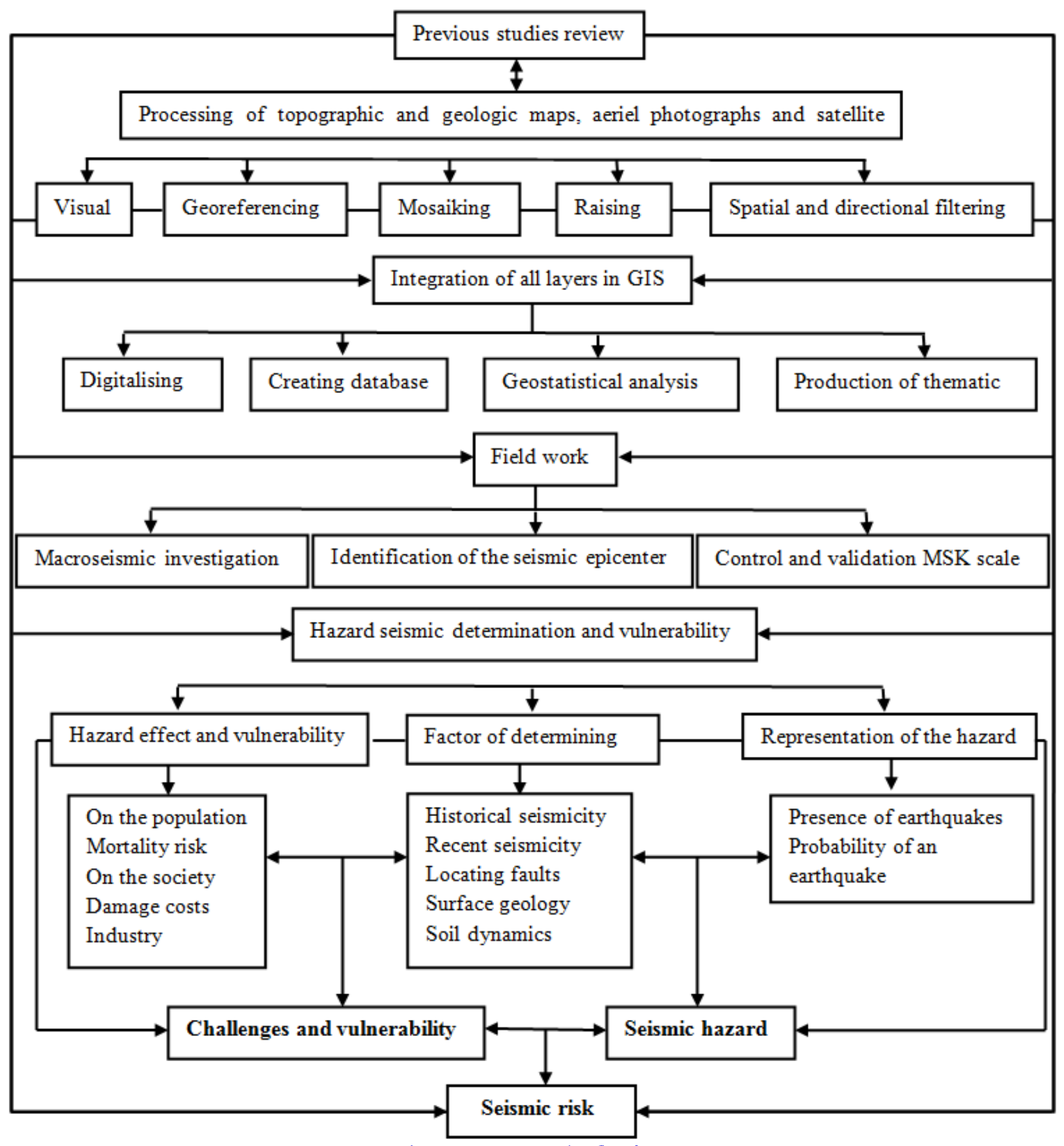

Figure 2. Data processing flowchart.

To understand the seismotectonic framework of the Metlaoui region, a seismotectonic map Figure 3 was developed to cover the city of Metlaoui and its surroundings within a radius of $100 \mathrm{~km}$. This map has allowed us to identify two shortening directions: the first oriented NW-SE to NNW-SSE and the second direction West-East (Dlala, 1992). The calculated epicenters are distributed and concentrated around active faults known as active faults such as the Gafsa fault in direction N120, the Séhib fault in direction N135, the Metlaoui fault and that of the North of the Chotts in direction N90 (Zargouni, 1986). The large distribution of epicenters around the city of Metlaoui confirms that the latter is a privileged center of earthquakes.

A more detailed study at the level of the Metlaoui region shows that the epicenter of the main earthquake of the 7/11/1989 earthquake is located a few kilometers south of this city. It should be noted, according to neotectonic, seismotectonic and microtectonic data that this earthquake was triggered by a compressive stress field NW-SE which characterizes this region (Dlala \& Hfaidh, 1993). 


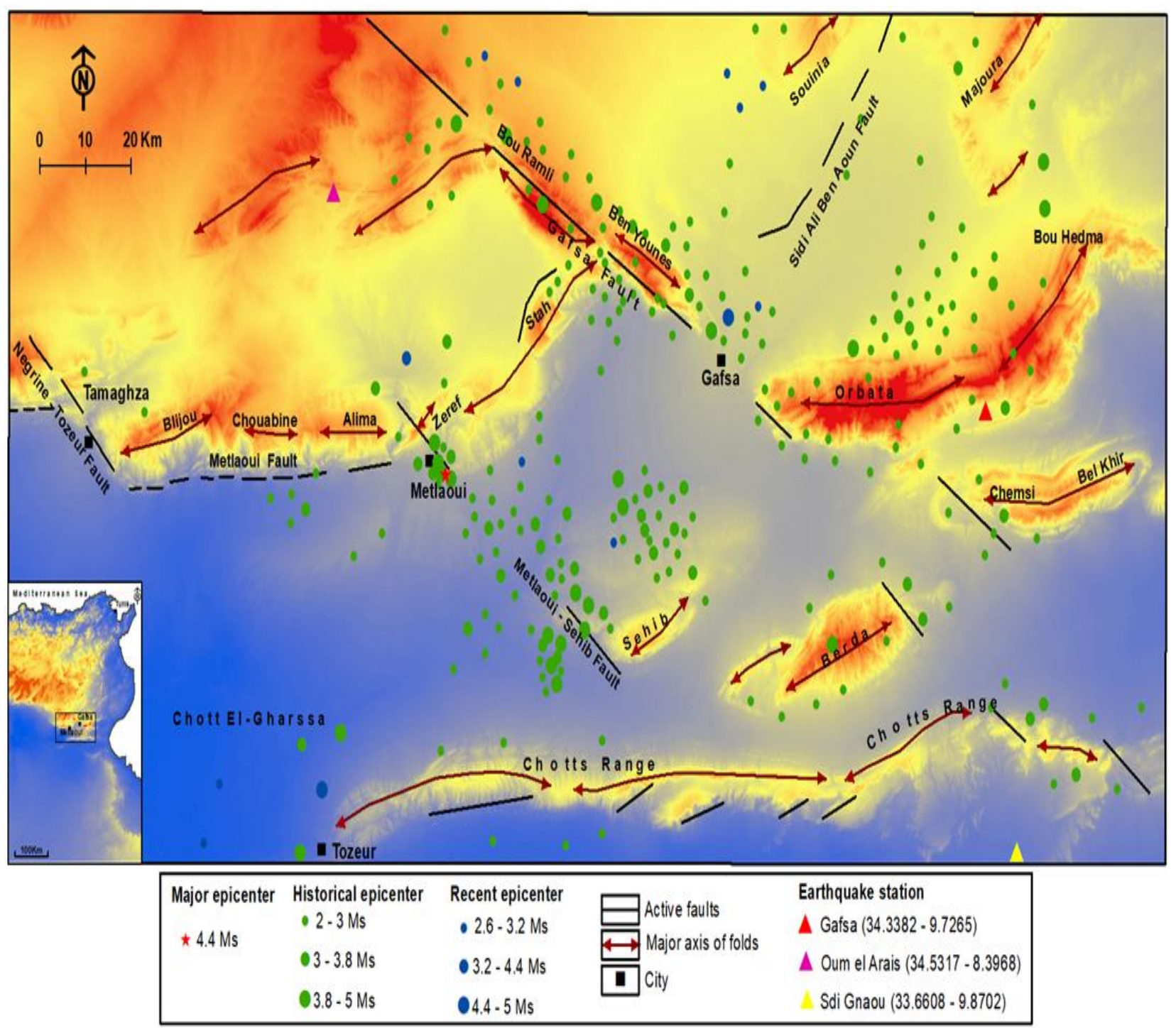

Figure 3. Seismotectonic map of the Metlaoui region within a radius of $100 \mathrm{Km}$.

For the morpho-tectonic framework, a map of Geological and tectonic lineaments Figure 4 is established through topographic maps, the interpretation of aerial photos, type directional filtering (Sobel, Roberts, etc.), as well as through the application of various data fusion processing and spectral indices on Landsat-7 ETM + and ASTER satellite images of the Metlaoui region. In order to obtain a map of the probable lineaments, the combination and the superposition of the information drawn from these supports with the data of the geological map, of the bibliography and of field observations made it possible to identify the sure tectonic accidents.

The simplified map of tectonic lineaments revealed the important role of neotectonics in the arrangement of forms and formations at the level of the Metlaoui ridge and its southern foothills.

This work has two major objectives: i) To identify the influence of tectonic processes on the arrangement of landforms both in mountains and on the foothills, and ii) To address the probable role of certain accidents in the recent evolution of the relief south of the Metlaoui range and in the intensity of the current seismic events ». 


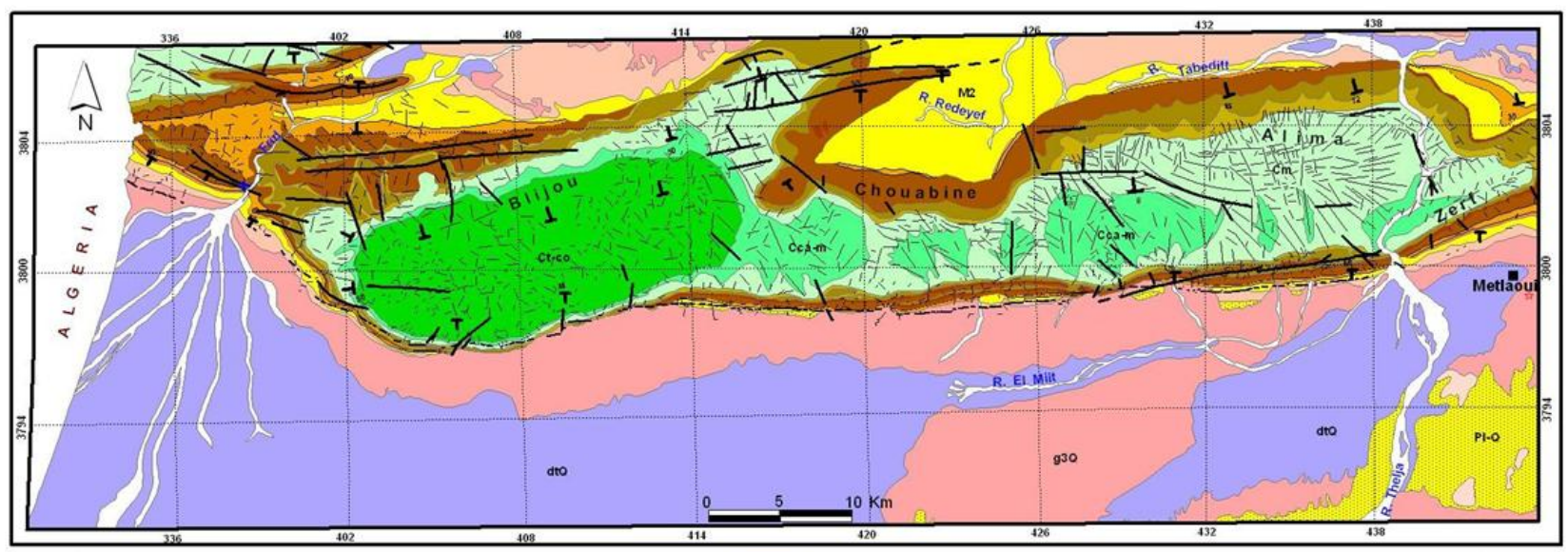

\begin{tabular}{|c|c|c|c|}
\hline & Recent alluvial of river & $\overline{\text { P2 }}$ & Alternation of lumachelles, clays, dolomite and gypsum \\
\hline dtQ & $\begin{array}{l}\text { Coarse to medium deposits of the low } \\
\text { terrace and a eolien deposits }\end{array}$ & P1 & OfTHELJA formation \\
\hline g30 & Silt and clays gypsum clays of middle terrace & $\mathbf{c m}$ & White limestones and green clays - Blackish of upper BERDA formation \\
\hline 940 & Coarse deposits of upper with achetienne industry & cca-m & Clay, marl and limestone of middle BERDA formation \\
\hline P1-Q & Sandy clays and conglomerates of SEGUI formation & Cca & Clay and limestone rich Orbitoides of lower BERDA formation \\
\hline M3PI & Clays in sandy with conglomeratic past & cs & $\begin{array}{l}\text { Green clay brachiopods of STAH formation } \\
\text { and dolomitic limestone riche inoceramids of AIN DRIMA formation }\end{array}$ \\
\hline M2 & $\begin{array}{l}\text { Clay alternations sands of BEGLIA formation } \\
\text { Clay red sanders helecides of SEHIB formation }\end{array}$ & & Certainly faults \\
\hline El-p & $\begin{array}{l}\text { Gypsum in past few dolomitic and white } \\
\text { dolomites of SEUGDAL formation }\end{array}$ & & $\begin{array}{l}\text { Probable faults } \\
\text { Value and trend of dip }\end{array}$ \\
\hline Ey-1 & Dolomitic limestone bars of KEF ED DOUR formation & - & City \\
\hline Ey & Clays and phosphate series of CHOUABINE formation & मे & Major epicenter \\
\hline
\end{tabular}

Figure 4. Geological and tectonic lineaments map of Metlaoui region.

\section{RESULTS}

The faults identified during the fieldwork are: the Metlaoui directional fault; the Mtalga-Metlaoui fault (BenOuezdou \& Zargouni, 1988) and the Thèlja-Metlaoui fault (Aliouet, 2017) which constitutes the extension towards the North of the Séhib fault. A more detailed study at the level of the Metlaoui region shows that the epicenter of the main earthquake of the 7/11/1989 is located a few kilometers south of the city of Metlaoui. In this area, the Metlaoui N90, Metlaoui-Mtalga N70 and the Metlaoui-Thelja N30 faults slipped during the recent Quaternary. The historical and instrumental seismicity data confirm that the seismicity of the Metlaoui region and its surroundings is related to the same earthquake fault.

\subsection{Seismic Hazard Assessment in the Metlaoui Region}

The Metlaoui region, as recorded in its seismic history about ten major events according to the catalogue of the National Institute of Metrology, Attafi (1973) is characterized by moderate magnitudes and maximum intensity levels that varied between VI and VII Table 2.

Table 2. Some seismic events in the Metlaoui region (INM).

\begin{tabular}{c|c|c}
\hline Date & Magnitudes (Richter) & Intensity (MSK) \\
\hline $25 / 08 / 1911$ & 4.40 & VI \\
\hline $25 / 04 / 1912$ & 4.40 & VI \\
\hline $25 / 02 / 1916$ & 4.40 & VI \\
\hline $22 / 05 / 1972$ & 5.00 & VII \\
\hline $07 / 11 / 1989$ & 4.40 & VI \\
\hline $05 / 11 / 1990$ & 3.20 & VI \\
\hline $11 / 05 / 1994$ & 4.50 & VI \\
\hline $23 / 03 / 1996$ & 3.30 & VI \\
\hline $04 / 04 / 2008$ & 2.43 & III \\
\hline $12 / 08 / 2009$ & 2.93 & VI \\
\hline $29 / 04 / 2014$ & 2.08 & II \\
\hline
\end{tabular}


The earthquake of 7/11/1989, was recorded by the Sidi Gnaou station Figure 5. It was the most important in the Metlaoui region since the event of May 22, 1972 (Ms 4.2, Intensity VII).

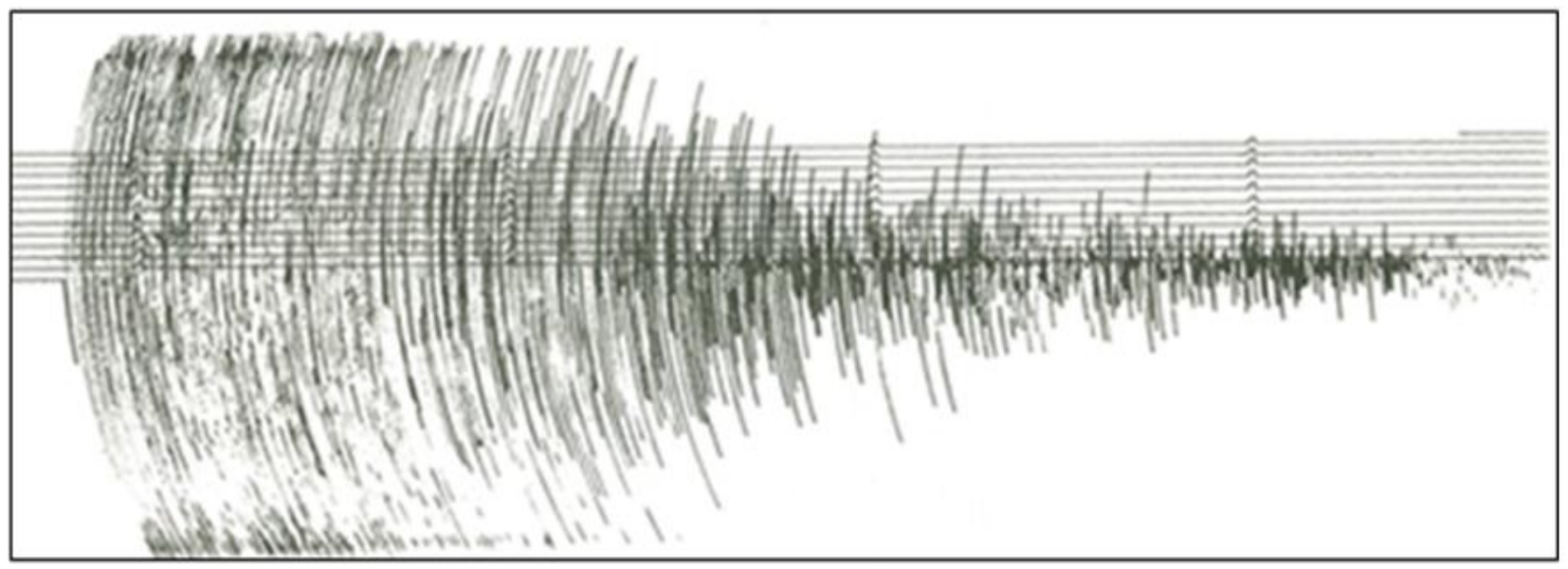

Figure 5. Earthquake of 7/11/1989 Ms = 4.4 Sidi Gnaou station.

To begin this task we have gathered the available data of historical and instrumental seismicity. A map of the distribution of intensities of the Metlaoui region within a radius of $100 \mathrm{~km}$ has been drawn up Figure 6. The latter shows the existence of four zones of strong seismic intensity varying between VI and VII (MSK intensity scale) such as the Metlaoui zone. Examination of the intensity map in the Metlaoui region shows that the orientation and distribution of the high intensities follow two alignments: West-East and North West-South East. This distribution is explained by the pre-existing faults.

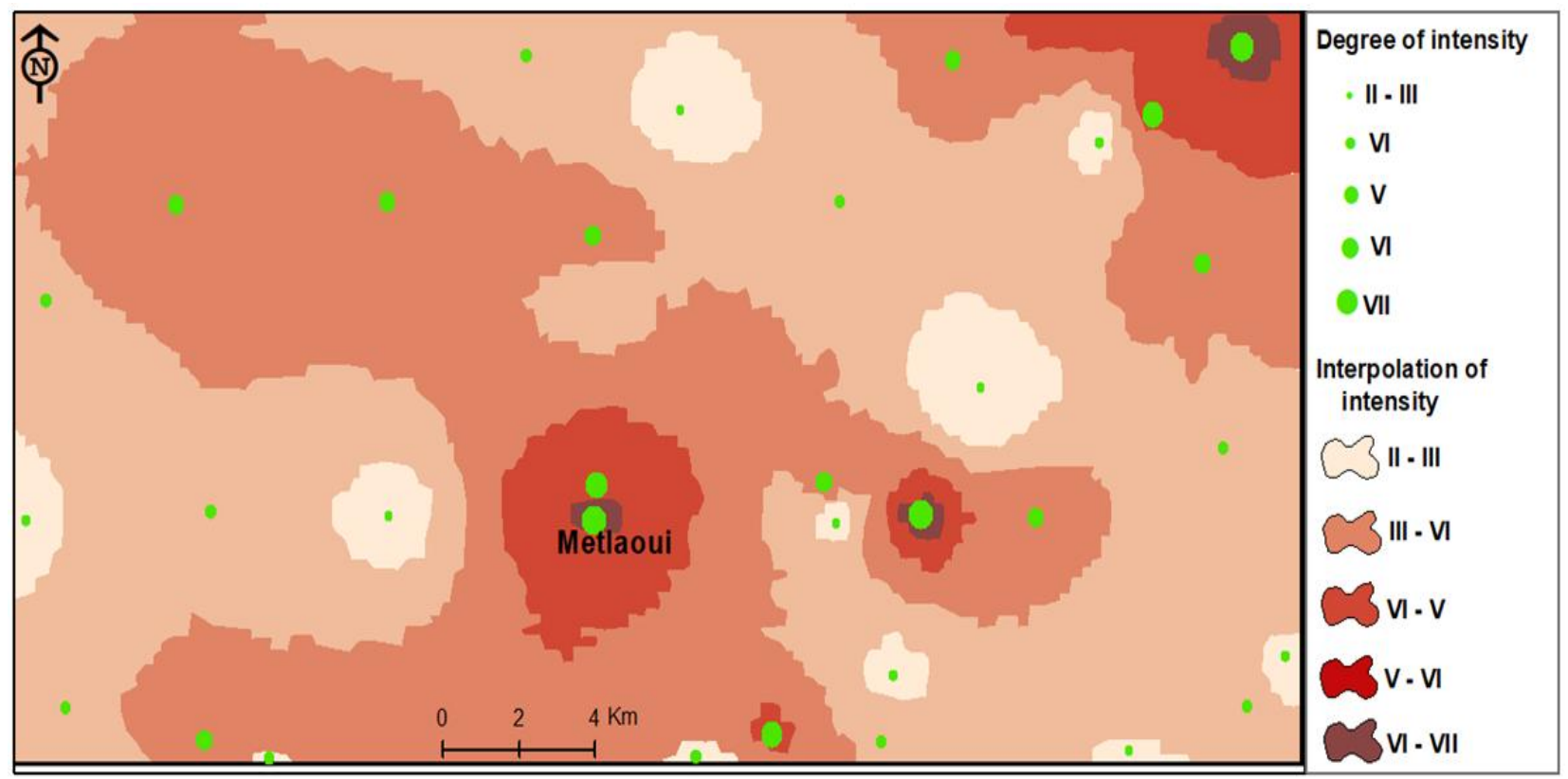

Figure 6. Simplified maximum intensity map in the Metlaoui region.

\subsection{The Effects of the Metlaoui Earthquake on Buildings}

The Housing Service of the Regional Directorate of Gafsa, was tasked, in the week following the magnitude 4.4 (Richter) seismic shock in Metlaoui on $7 / 11 / 1989$, to carry out an investigation to estimate the cost of damage linked to this earthquake. The survey showed that the earthquake resulted in a severe impact on buildings with 175 houses suffering very serious damage, around $35 \%$ of the total number of buildings observed Table 3. 
Table 3. Effect of the earthquake of 7/11/ 1989 on constructions in the Metlaoui region (Ministry of Equipment and Housing, Regional Directorate of Gafsa)

\begin{tabular}{c|l|l|c|c|c}
\hline Number & Locality & Deanship & $\begin{array}{c}\text { Number of } \\
\text { constructions } \\
\text { observed }\end{array}$ & $\begin{array}{c}\text { Number of } \\
\text { constructions with } \\
\text { low disorders }\end{array}$ & $\begin{array}{c}\text { Number of } \\
\text { constructions with } \\
\text { severe disorders }\end{array}$ \\
\hline 1 & El Kaîna & Mzirâa & 15 & 6 & 9 \\
\hline 2 & Magroune1 & Mzirâa & 12 & 2 & 10 \\
\hline 3 & Magroune2 & Mzirâa & 07 & 0 & 7 \\
\hline 4 & Oued Lartha & Mzirâa & 22 & 0 & 6 \\
\hline 5 & Ouled Ousaif & Mzirâa & 06 & 0 & 43 \\
\hline 6 & Mzirâa & Mzirâa & 98 & 7 & 6 \\
\hline 7 & Ennouhoudh & El markez & 66 & 4 & 4 \\
\hline 8 & Moderne & El markez & 13 & 4 & 24 \\
\hline 9 & El Amel & El markez & 41 & 3 & 4 \\
\hline 10 & Ezourour 1 et 2 & El mahata & 43 & 8 & 1 \\
\hline 11 & Esâada East & El mahata & 71 & 5 & 21 \\
\hline 12 & jeune & El mahata & 15 & 0 & 4 \\
\hline 13 & Ennassim & El mahata & 4 & 9 & 175 \\
\hline 14 & Esâada West & El mahata & 64 & 2 & 4 \\
\hline Totale & El Majaji & El markez & 28 & 56 & \\
\hline
\end{tabular}

The earthquake caused very high damage in old buildings in several localities of the city of Metlaoui. Walls and roofs collapsed and large, deep cracks were observed. Fortunately no loss of human life was recorded

\section{DISCUSSION}

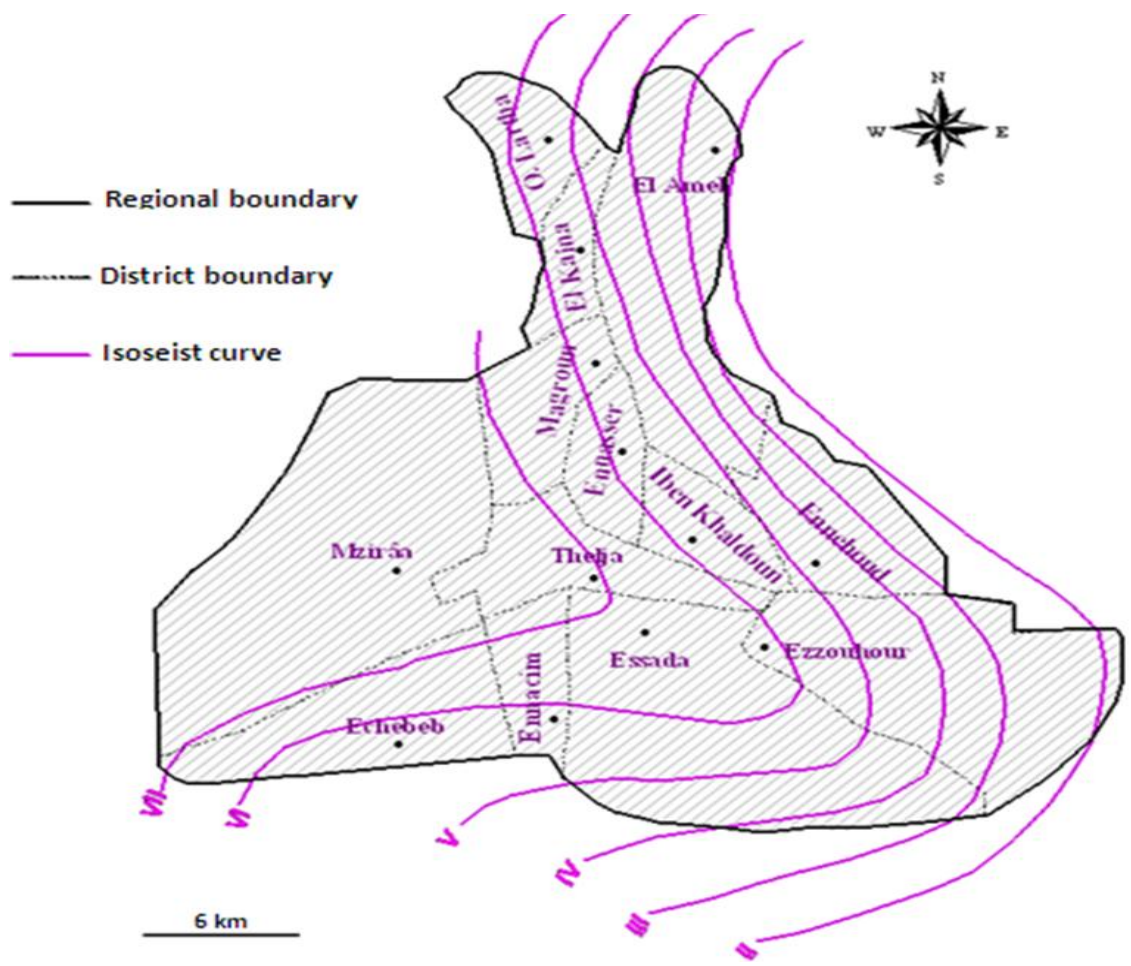

Figure 7. Isoseism map generalized in the Metlaoui city.

\subsection{Macroseismic Investigation}

A macroseismic survey was carried out in Metlaoui to investigate the effects of the earthquake of $7 / 11 / 1989$. It was based on a hundred questionnaires, which were distributed to the population of the affected areas. We interpreted the information gathered using the MSK intensity scale to determine intensity levels. The distribution 
of intensity levels allowed us to identify the areas of highest intensity, which were used to determine the epicentral zone and produce the isoseistic curve map. The investigation carried out on the assessment of the cost of the damage relating to the material losses caused by this earthquake allowed us to clarify the assessment of the intensities in the disaster area. All localities affected by the earthquake of 7/11/1989 were classified according to the degree of intensity of damage using the MSK scale. This classification allowed us to establish the isoseismal map Figure 7.

\subsection{Determination of the Seismic Hazard}

The evaluation of the seismic hazard amounts to quantifying, for a given region, the possibility of being subjected to seismic shock of given characteristics. To determine the seismic hazard in the Metlaoui region, which is experiencing active seismicity, it is necessary to evoke the destructive characteristics of the earthquake of 7/11/1989. The census which was carried out by the Regional Directorate of Gafsa (Ministry of Equipment and Housing), as part of the assessment of the extent of the seismic risk. It shows that this earthquake was threatening for human life and especially its destructive character for buildings. Thus, around 231 buildings were damaged compared to the total number of buildings observed Table 4.

Table 4. Relative frequency of buildings affected by the earthquake of 7/11/1989 (according to the regional management of Gafsa, ministry of equipment and housing).

\begin{tabular}{|c|c|c|c|c|c|}
\hline Number & Locality & Deanship & $\begin{array}{c}\text { Number of } \\
\text { constructions } \\
\text { observed } \\
\end{array}$ & $\begin{array}{l}\text { Number of } \\
\text { damaged } \\
\text { buildings }\end{array}$ & $\begin{array}{c}\text { Frequency relating } \\
\text { to damaged } \\
\text { buildings }\end{array}$ \\
\hline 1 & El Kaina & Mziraa & 15 & 15 & 6.50 \\
\hline 2 & Magroun 1 & Mziraa & 12 & 12 & 5.19 \\
\hline 3 & Magroun 2 & Mziraa & 7 & 7 & 2.99 \\
\hline 4 & Oued Lartha & Mziraa & 22 & 15 & 6.50 \\
\hline 5 & Ouled Oussaief & Mziraa & 6 & 6 & 2.59 \\
\hline 6 & Mziraa & Mziraa & 98 & 50 & 21.65 \\
\hline 7 & Ennouhoudh & El Markaz & 66 & 10 & 4.32 \\
\hline 8 & Moderne & El Markaz & 13 & 8 & 3.46 \\
\hline 9 & Malaji & El Markaz & 28 & 6 & 2.59 \\
\hline 10 & El Amel & El Markaz & 41 & 4 & 1.73 \\
\hline 11 & Ezzouhour 1 et 2 & El Mahatta & 43 & 30 & 12.98 \\
\hline 12 & Essaada East & El Mahatta & 71 & 28 & 12.12 \\
\hline 13 & Le jeune & El Mahatta & 15 & 9 & 3.89 \\
\hline 14 & Ennassim & El Mahatta & 4 & 1 & 0.43 \\
\hline 15 & Essaada West & El Mahatta & 64 & 30 & 12.98 \\
\hline Total & & & 504 & 231 & 100 \\
\hline
\end{tabular}

The material damage caused by this earthquake was very significant. It generated total financial losses estimated at 224,525,000 Tunisian Dinars, with 61,100,000 Tunisian Dinars for the losses recorded in public buildings (Tables 5 and 6).

Table 5. The financial impact of the 7/11/1989 earthquake on buildings (Ministry of Equipment and Housing, Regional Directorate of Gafsa).

\begin{tabular}{l|c|c|c|c|c}
\hline The State's contribution is estimated at \\
\hline & $\begin{array}{c}\text { Number of } \\
\text { houssing }\end{array}$ & $\begin{array}{c}\text { Houssing cost } \\
\text { (dinars) }\end{array}$ & $\begin{array}{c}\text { Total costs } \\
\text { (dinars) }\end{array}$ & $\begin{array}{c}\text { Public } \\
\text { institutions }\end{array}$ & $\begin{array}{c}\text { Total costs (dinars) } \\
\text { Public institutions }\end{array}$ \\
\hline Category 2 & 13 & 461 & 5993 & Primary schools & 30100 OOO \\
\hline Category 3 & 383 & 204 & 78132 & Secondary schools & 13 OOO OOO \\
\hline Category 4 & 1755 & 80 & 140400 & Administrations & 18400 OOO \\
\hline Total & & 224525 & Total & 61100 OOO \\
\hline
\end{tabular}


Table 6. Financial implications of the 7/11/1989 earthquake on public institutions (Ministry

of Equipment and Housing, Regional Directorate of Gafsa).

\begin{tabular}{l|c}
\hline Public institutions & Damage values \\
\hline Primary schools & 2.500 .000 \\
\hline Modern city & 1.500 .00 \\
\hline El Kaina city & 2.700 .000 \\
\hline El Manjem city & 3.500 .000 \\
\hline Ennouhoud city & 4.500 .000 \\
\hline El Mahata city & 1.500 .000 \\
\hline Esâada city & 1.000 .000 \\
\hline Zouhour city & 1.500 .000 \\
\hline Road to Tozeur & 7.500 .000 \\
\hline Républic city & 2.200 .000 \\
\hline El Thèlja city & 2.100 .000 \\
\hline El MIzirâa city & 4.000 .000 \\
\hline Secondary schools & 2.000 .000 \\
\hline Metlaoui secondary school & 7.000 .000 \\
\hline Technic secondary school & \\
\hline Mixed secondary school & 700.000 \\
\hline Public administrations & 1.000 .000 \\
\hline Public bookstore & 5.500 .000 \\
\hline Finance recipe & 2.200 .000 \\
\hline The seat of Tribunal and Justice & 5.000 .000 \\
\hline Delegation center & 1.500 .000 \\
\hline The old hospital & 51.100 .000 \\
\hline Post center & \multicolumn{1}{l}{} \\
\hline Total & \\
\hline & \\
\hline
\end{tabular}

Indeed, this situation necessarily insists on finding solutions to this destructive phenomenon, to minimize material and bodily damage. Any study approach shows that the practice of the earthquake-resistant construction rule was an essential solution in all development programs in the future, both for the inhabitants (apartments, houses, etc.) and for the infrastructures (roads, bridges, etc.), as well. that the education of the populations of this region remains an important obligation to face the serious situation caused by this destructive catstrophy.

\subsection{Mapping of the Seismic Hazard}

Studies and research devoted to seismic hazard mapping are of paramount importance in the field of mitigation against this risk (Ksentini, 2004). Seismic hazard mapping is an essential element in its management since it allows thematic data to appear on the study area (extent of a risk, population, buildings, etc.) and to superimpose them.

It requires gathering all the data available on the morphotectonics, seismotectonics and seismicity of the region (historical and instrumental seismicity):

- List the faults that are known in the field since approximately more than $99 \%$ of earthquakes have occurred on existing faults.

- Draw up an inventory of past earthquakes in the study area; a historical map of earthquakes giving the location, date, intensity and magnitude is drawn up and a forecast is available to establish the hazard map taking into account foreseeable earthquakes (Ksentini, 2004).

- Study the consequences of current seismic events on buildings and human lives, in order to be able to identify the degree of vulnerability of the region studied in the face of the seismic risk which threatens it, to define the risk levels from the weakest to the strongest.

The shape of the isoseismal curves has in fact made it possible to define the risk levels from the weakest to the strongest; the highest level of risk corresponds to areas where the degrees of hazard and vulnerability range from 
relatively high to very high. It covers the areas closest to the corridor of the Thèlja-Metlaoui fault. The lowest level characterizes areas with low to relatively low threat level and / or vulnerability level.

The seismic hazard mapping remains a basic document for land use and urban planning in the city of Metlaoui. It is an essential tool in the prevention and management of crises. It covers the planner's expectations by providing answers to the knowledge of this hazard. It can help decision-makers and planners (Municipality, Ministry of Equipment and Housing ...) to orient the future expansion of the urban space of the city of Metlaoui and avoid the seismic risk corridor.

\section{CONCLUSION}

The study and cartographic approach of the seismic hazard in the Metlaoui region required collecting all possible information and updating the information collected. The analysis of the morpho tectonic and seismotectonic framework carried out in the area in question is a better recourse to better understand the network arrangement of the pre-existing faults. The latter prove a characteristic example of deformation in the recent Quaternary. They constitute an argument for neotectonic activity in the Metlaoui region and in the southwest of Tunisia. It would probably be the seismogenic source of all the seismic events recorded in this region, in particular the earthquake of $7 / 11 / 1989$. The concentration of epicenters around the city of Metlaoui confirms that the latteris an area very vulnerable to seismic risk.

The examination of seismotectonic maps, of maximum intensities, isoseismal and generalized macroseismic investigation in the Metlaoui region have made it possible to identify areas with high seismicity which correspond to areas with degrees of hazard and vulnerabilities range from relatively high to very high. It also appears that the extension of the urban fabric does not take into account the seismo-tectonic risk. These new data should better guide the development and urban planning projects of the city of Metlaoui.

Funding: This study received no specific financial support.

Competing Interests: The authors declare that they have no competing interests.

Authors' Contributions: Both authors contributed equally to the conception and design of the study.

\section{REFERENCES}

Aliouet, S. (2017). The mountain range of Metlaoui and its southern foothills. Thesis Doct. Faculty of Humanities and Social Sciences of Tunis.

Aliouet, S., Soudani, K., Melki, F., \& Ahmed, B. (2020). Complementarity of optical remote sensing and geographic information system for detection and mapping of geological lineaments: A case study in the Metlaoui Region in Southern Tunisia. Journal Remote Sens GIS, 9, 277.

Allen, T., Griffin, J., \& Clark, D. (2018a). The 2018 national seismic hazard assessment for Australia: Model input files. Geoscience Australia record 2018/32. Canberra, ACT, Australia: Geoscience Australia.

Allen, T. I., Griffin, J. D., Leonard, M., Clark, D. J., \& Ghasemi, H. (2020). The 2018 national seismic hazard assessment of Australia: Quantifying hazard changes and model uncertainties. Earthquake Spectra, 36(1_suppl), 5-43.

Attafi, K. (1973). National institute of metrology (pp. 85). Internal Report.

Ben-Ouezdou, H., \& Zargouni, F. (1988). New data about the Quaternary and recent tectonics in the Metlaoui range (southwest of Tunisia). Mediterranean, 64(2), 22-26

Ben-Ouezdou, H. (1994). The southern part of the Tunisian steppes, geomorphological study. Doctoral Thesis States Letters. Univ. Tunis I.

Castany, G. (1953). Quaternary orogeny in the region of Gafsa. Bull. Soc. Nat. From Tunisia, 6(1-4), 151-160.

Castany, G., \& EG., G. (1954). Quaternary morphology, paleontology and their relations in Gafsa (pp. 9-37). Libica, Algiers.

Coque, R., \& Jauzein, A. (1965). Le quaternaire en Tunisie (pp. 139-154). Roma: Quaternaria.

Dlala, M. (1992). Active compression tectonics of southern Tunisia: Seismotectonic implication. Annal Geology. Tunis, 1, 185-190. 
Dlala, M., \& Hfaidh, M. (1993). The earthquake of November 7, 1989 in Metlaoui (Southern Tunisia): An active tectonics in compression C.R (Vol. 317, pp. 1297-1302). Paris: Accademic Science.

Gasmi, A. (2012). The western part of the Southern low plains (Southwest of Tunisia): Geomorphology and evolution of the natural environment. Doctoral Thesis States Letters Univ Tunis I.

Ghasemi, H., Cummins, P., Weatherill, G., McKee, C., Hazelwood, M., \& Allen, T. (2020). Seismotectonic model and probabilistic seismic hazard assessment for Papua New Guinea. Bulletin of Earthquake Engineering, 18(15), 6571-6605.

Ksentini, A. (2004). Contribution of geographic information systems in the analysis and management of seismic risk. INIT. Tunis. Master Memory.

Rashad, S., José, A., \& Peláez, H. M. (2020). Probabilistic seismic Hazard assessment for United Arab Emirates, Qatar and Bahrain. Appl. Science, 10(790), 1-29.

Roux, H. (1911). The folds around Redeyef (Southern Tunisia). Bulletin of the Geological Society of France, 4, $249-284$.

Said, A. (2011). Active tectonics of the South Tunisian Atlas: structural and morphotectonic approach. Toulouse III University Thesis Paul Sabatier.

Vaufrey, R. (1932). The Acheulean-Mousterian folds of the alluvium of Gafsa. Journal of Dynamic Geology and Physical Geography, t., 299-321.

Zargouni, F. (1984). Style and chronology of the deformations of the structures of the southern Tunisian Atlas. Recent evolution of the South Atlas Accident. Minutes of the Sessions of the Academy of Sciences, 299(2), 71-76.

Zargouni, F. (1986). Tectonics of the Southern Atlas of Tunisia: Geometric and kinematic evolution of structures in shear zones (pp. 304). Tunis: Sci. Earth. INSRT.

Views and opinions expressed in this article are the views and opinions of the author(s), International Journal of Geography and Geology shall not be responsible or answerable for any loss, damage or liability etc. caused in relation to/arising out of the use of the content. 